\title{
Marine derived tyrosinase inhibitors
}

\section{Deniz kaynaklı tirozinaz inhibitörleri}

\author{
Amine Dilara Pilevneli1* • Belma Konuklugil2 \\ ${ }^{1}$ Ankara University Faculty of Pharmacy, Department of Pharmacognosy, 06560 Ankara, Turkey \\ https://orcid.org/0000-0001-8573-2718 \\ ${ }^{2}$ Ankara University Faculty of Pharmacy, Department of Pharmacognosy, 06560 Ankara, Turkey \\ https://orcid.org/0000-0002-4753-0450
}

Pilevneli A.D. \& Konuklugil, B. (2020). Marine derived tyrosinase inhibitors. Ege Journal of Fisheries and Aquatic Sciences, 37(4), 427-436. DOI: 10.12714/egejfas.37.4.15

Abstract: The cosmetics industry has gained strong momentum all over the world in recent years and has become a growing and promising sector. As it is known, as in the pharmaceutical industry, the cosmetic industry has also turned into becoming marine resources by seeking new materials for its continuation to be more productive for the field. To serve this purpose, marine-derived substances are highly claimed to be an interesting as well as a fruitful source for the benefits of the cosmetics industry. In this respect, as known globally, anti-tyrosinase inhibitors used in skin whitening are obtained from a considerable number of marine organisms. In this regard, the main objective of this article is to summarize a highly significant number of natural products derived from marine sources such as algae, fungi, seaweeds and bacteria which are known to have shown anti-tyrosinase activity.

Keywords: anti-tyrosinase, skin whitening, cosmetic, marine-derived organisms

Öz: Kozmetik sektörü son yıllarda çok güçlü bir ivme kazanmış ve tüm dünyada gelecek vaad eden bir sektör haline gelmiştir. Illaç endüstrisinde olduğu gibi, kozmetik endüstrisinde de yeni maddeler arama çabasıyla denizel kaynaklara yönelinmiștir. Bu nedenle, deniz kaynaklı kimyasalların kozmetik endüstrisinin yararı için ilginç ve verimli bir kaynak olduğu düşünülmektedir. Bilindiği gibi, cilt beyazlatma amacıyla kullanılan anti-tirozinaz inhibitörleri, önemli sayıda deniz organizmasından elde edilmektedir. Bu bağlamda, bu makalenin ana amacı, anti-tirozinaz aktivitesi gösterdiği bilinen alg, mantar, deniz yosunu ve bakteri gibi deniz kaynaklarından elde edilen çok sayıda doğal ürün hakkında bilgi vermektedir.

Anahtar kelimeler: anti-tirozinaz, cilt beyazlatma, kozmetik, deniz kaynaklı organizmalar

\section{INTRODUCTION}

As it is highly and widely known, cosmetic products containing biologically active compounds are believed to be used to improve the appearance of the skin as well as improving the physiological effects of the cells. For the continuation of cosmetic developments, it is highly important and an undeniable fact to discover new bioactive substances from natural sources which are regarded as resourceful, safe, and stable (Uppala, 2015). Consumers have been demanding the use of more natural ingredients due to some negative ideas regarding chemicals and toxic substances over the past years. (Muda et al., 2017). More recently, the cosmetic industry has combined creams, lotions, and ointments with bioactive substances and it is classified as a special class of products. More interestingly, the number of cosmetic companies which are highly interested in incorporating extracts from coastal plants, marine algae, seaweeds and sea minerals into cosmetic components is obviously on the rise.

To continue with a considerable amount of background information as to the field, it may be stated that some studies carried out globally have shown that, in recent years, the cosmetics industry has been focusing on and paying more and more attention to obtain new molecules from marine sources like the pharmaceutical industry (Sumathy and Kim, 2011).
On the one hand, marine-based natural products have turned out to be a crucial field of research with great amount of economic returns attracting a large number of scientists all over the world. According to the Euro Ocean, there are around 600 European marine projects funded by both FP6 and FP7 actions, which is known to contribute to the introduction of more marine bioactive products for the market.

The marine environment is claimed to be so productive that it may provide a great amount as well as numerous resources for the discovery of new active substances to be used in the industry effectively. Despite the chemical and biological diversity of marine environment, very little has been known to be discovered until now. The desire to have a protection against ultraviolet rays, to improve the appearance and anti-aging demands has expanded the market for new cosmetic components. More natural products have been created upon the current demands in the industry. An increasing number of new molecules from the marine environment reveals a number of strong and effective activities on the skin. Secondary metabolites isolated from macrophages showed various activities (antioxidant, antiaging, and anti-inflammatory activities) (Brunt and Burgess, 2018). Throughout this review, the main purpose of marinederived tyrosinase inhibitors has been introduced in a detailed way. 


\section{Cosmetic/s}

Cosmetics is known to be used as a term that originally comes from the Greek word kos-metikos which means to a master in fix. For thousands of years, men and women have been known to use cosmetics for the following purposes: ointment, lotions, perfumes, and so on in order to be more become beautiful, to look much younger, to hide wrinkles, scars, pimples or for a variety of scars on their faces, to protect their skin from the sun, wind and cold, to remove the unwanted hair from their bodies, and to prevent hair loss (Çomoglu, 2012).

The cosmetic sector is considered to be a rapidly developing and a promising sector and the revenues are expected to increase in the next decade. Many years after Shu Uemura firm combined deep seawater with skincare and makeup products, his profound interest in the marine ingredients of the cosmetic industry is believed to have increased continuously by making a considerable amount of progresses in the industry (Martins et al., 2014).

Asian women are known to prefer white skin and due to that reason, over the last decade, skin whitening products have had the largest share in the skincare market in Asia (Boonme et al., 2009). Almost 15\% of the world's population, especially in Asian countries, are believed to use skin whitening products (Pillaiyar et al., 2017).

\section{Skin and melanin}

Skin is highly known to be a physiological barrier that protects the body against harmful factors. Keratinocytes and melanocytes continuosly function to form the outermost layer of the epidermis where melanin is known to be synthesized. Melanin is considered to play an important role in defending against harmful UV rays and reactive oxygen species. Melanin is also known to determine the color of hair, skin, and eyes depending on quantity, quality and distribution. Moreover, melanin synthesis disorders are believed to cause problems in skin pigmentation (Alğın Yapar, 2016).

Two forms of melanin are believed to be as follows; pheomelanin (yellow/red) and eumelanin (brown/ black). They are regarded as the main cause of ethnic skin color differences in the world. Melanin is synthesized in lysosomelike organelles called melanosomes within melanocyte cells. Melanogenesis is the production of melanin and is regulated by the activity of three enzymes, tyrosinase, Tyrosinaserelated protein1 (TRP1), and Tyrosinase-related protein2 (TRP2). Of these, tyrosinase is the one known to be the fundamentally main determinant of melanogenesis. The first stage in melanin synthesis is known to be highly critical with tyrosinase transformations leading to the formation of eumelanin and the formation of pheomelanin in the presence of cysteine and glutathione, while the other stages are proceed spontaneously at physiological $\mathrm{pH}$. Hence, genetic factors are known to play an essential role in melanogenesis, whereas hormones proopiomelanocortin-derived peptides stimulate pigmentation, particularly in the sun-exposed areas, and other paracrine factors that are known to determine skin color include endothelin-1, stem cell factor, prostaglandins, and catecholamines (Alğın Yapar, 2016).

Some compounds such as hydroquinone, arbutin and kojic acids have been used for skin whitening; however, symptoms such as contact dermatitis and skin irritation may occur after a prolonged use of these compounds. Therefore, new, active and safe hypopigmenting agents are being investigated. Under such conditions, nature is regarded as the most important and productive resource for these researches, and previous studies demonstrate this (Kim et al., 2017).

An increase in melanin production and accumulation may result in increased skin alignments and may cause hyperpigmentations such as melism, proinflammatory melanoderma, solar lentigo, etc. Hyperpigmentation of the epidermis and dermis are believed to depend on the increased number of melanocytes or enzyme activity.

\section{Pigmentation of the skin}

Pigmentation of the skin is considered to occur as a consequence of a variety of physiological processes. These; $i$. development of melanocytes, ii. density of melanocytes, iii. structural and enzymatic formations in melanosomes, iv. melanin synthesis, v. transfer of melanosomes to dendrites, vi. transfer of melanosomes to keratinocytes; and vii. melanin is known to be an important process of the distribution of the suprabasal layers of the skin. The first three are purely genetic, while the last four are targeted by skin whiteners (Alğın Yapar, 2016).

\section{Tyrosinase}

Tyrosinase (EC 1.14.18.1) is also regarded as polyphenol oxidase, monophenol oxidase, phenolase or catecholase and that contains copper. Its function is known to catalyze the hydroxylation of L-tyrosine to 3,4-dihydroxyphenylalanine (LDOPA) and the subsequent oxidation of L-DOPA to dopaquinone (Figure 1) (Vamos-Vigyazo, 1981). The name tyrosinase is used because of the specificity of the enzyme against tyrosine (monohydroxyphenylalanine) and dihydroxyphylalanine as the substrate (Whitaker, 1994).

Tyrosinase is highly believed to be very common in nature (Cooksey et al., 1997). It is widely distributed in plants, microorganisms and usually found in fungi and some animal organs (Parvez et al., 2007). Tyrosine is known to be hydroxylated with monophenolase. 3,4dihydroxyphenylalanine (L-DOPA) is oxidized with diphenolase and converted into o-dopakinone. O-dopakinone is unstable in aqueous solutions and gives a rapid nonenzymatic reaction (Rodriguez-López J. et al., 1991).

The function of tyrosinase is believed to catalyze melanin in melanocytes through three different reactions in the biosynthetic pathway: First pathway; hydroxylation of tyrosine to L-DOPA. The second way; Oxidation of L-DOPA to dopakinone. In addition, the third way is the conversion of dopakinone to melanin in a series of complex reactions including cyclization and oxidative polymerization (Sugumaran, 1991). 


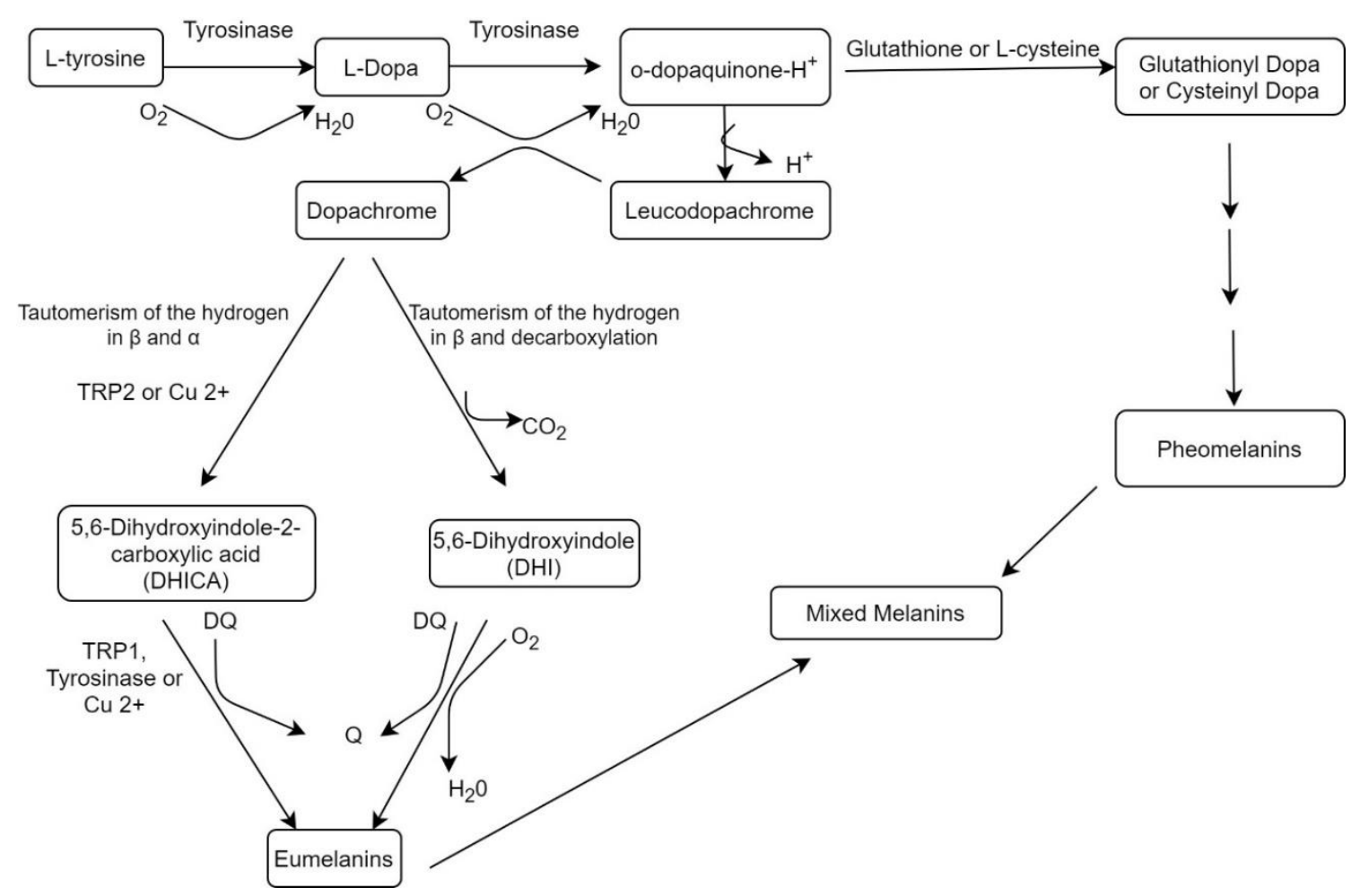

Figure 1. Scheme of the biosynthetic pathway of eumelanins and pheomelanins (Zolghadri et al., 2019)

Melanin biosynthesis is believed to be inhibited by tyrosinase inhibition. Therefore, tyrosinase inhibitors may be useful in clinical applications for the treatment of certain dermatological diseases associated with melanin hyperpigmentation. It is used in the cosmetics industry for whitening and skin whitening after the sunburn (Abd El Hady et al., 2014).

Tyrosinase is highly known to play a primordial role in the biosynthesis of melanin as well as microorganisms that are believed to affect skin color and pigmentation. Considering the medical and cosmetic sector, it may be stated that there are many studies focusing on isolation of the tyrosinase inhibitor compounds made of terrestrial and the marine environment which belong to chemical classes such as phenolic compounds (flavonoids, ligands, stilbenes, coumarins, arylbenzofurans, tannins), megastigmines (norisoprenoid), terpenes, cyclic peptides, alkaloids, and steroids.

The previous studies have obviously indicated that flavonoids are found to act as cofactors or substrates as well as their ability to chelate the active site of tyrosinase and thus it inhibits its effects (Kubo et al., 2000; No et al., 1999). Furthermore, flavonoids with a 4-substituted resorcinol unit in ring $B$ are considered to be potent tyrosinase inhibitors (Shimizu et al., 2000). The compounds made of the terpene group have shown tyrosinase inhibitory activities due to its position and relative configuration of the hydroxyl groups as well as the nature and number of sugar units like in the cycloartane glycosides (Wu and Naranmadura, 2014). In addition to the previous studies, it could also be said that an important amount of consideration of some alkaloids is that tyrosinase inhibitor capacities may be due to the allosteric effects on the enzyme (Lo et al., 2009; Wu and Naranmadura, 2014).

\section{Anti tyrosinase activity from marine sources}

Depending on the studies carried out widely, it may be stated that there are more than 250,000 species described in the oceans up to date, whereas thousands are still waiting to be discovered (Corinaldesi et al., 2017; Mora et al., 2011). More than 25,000 new biologically active compounds have been identified from marine sources (Blunt et al., 2015). Bacteria and algae are the major sources of active ingredients. Furthermore, bacteria and algae are commonly known and regarded as the most important sources of biologically active substances. Recently, the focus has been on the discovery of skin whitening compounds from many marine microorganisms. Among them, zeaxanthin appears to be of particular interest and can be obtained from Nannochloropsis oculata (Guillerme et al., 2017; Shen et al., 2011).

A considerable number of recent studies have revealed that marine-derived fungi (MDF) from sponges are a new productive and fruitful source of bioactive metabolites with a high potential for the pharmaceutical industry. Thus, by considering the high species diversity and distribution of sponges over large areas, it may be pointed out that they are expected to host marine fungi that can produce a wide variety 
of secondary metabolites. Those associated with sponges have higher species diversity and are highly effective in the production of secondary metabolites than fungi from other marine sources. Fungi symbiotes of sponges have recently attracted a promising amount of particular attention due to their capacity to produce new bioactive metabolites effectively. Marine fungi associated with sponges produce new bioactive metabolites with antibiotic, antitumor, antioxidant, antifungal, antialgal, anti-insect and acetylcholinesterase inhibitory effects (Abd El Hady et al., 2014; Almeida et al., 2011; Kjer et al., 2010; Lee et al., 2011; Mostafa et al., 2010; Thirunavukkarasu et al., 2012).

Table 1. Examples of marine active substances whose effects have been seen as a result of studies (D'Orazio et al., 2012; Fiorucci et al., 2012; Liu et al., 2006; Nastrucci et al., 2012).

\begin{tabular}{|c|c|c|}
\hline Compound name & Organism & Mode of action \\
\hline Cytarabin, ARA-C & $\begin{array}{l}\text { Sponge: Cryptotethia } \\
\text { crypta }\end{array}$ & $\begin{array}{l}\text { DNA Polymerase } \\
\text { Inhibitor }\end{array}$ \\
\hline $\begin{array}{l}\text { Trabectedin } \\
\text { (ET-743), } \\
\text { Yondelis } ®\end{array}$ & $\begin{array}{c}\text { Tunicate: Ecteinascidia } \\
\text { turbinate }\end{array}$ & $\begin{array}{l}\text { Binding to minor } \\
\text { groove DNA } \\
\text { alkilating } \\
\text { Guanine at N2 }\end{array}$ \\
\hline $\begin{array}{l}\text { Eribulin Mesylate } \\
\text { (E7389), Halaven } \AA\end{array}$ & $\begin{array}{c}\text { Sponge: Halichondria } \\
\text { okaday, } \\
\text { Axinella carteri } \\
\text { (Halichondrin B) }\end{array}$ & $\begin{array}{l}\text { Microtubule } \\
\text { interfering } \\
\text { agent }\end{array}$ \\
\hline Bromophenol & $\begin{array}{c}\text { Red alga: Polysiphonia } \\
\text { urceolata }\end{array}$ & $\begin{array}{l}\text { Protein tyrosine } \\
\text { phosphatase 1B } \\
\text { inhibitor }\end{array}$ \\
\hline Theonellasterol & Theonella swinhoei & $\begin{array}{c}\text { Selective Farnesoid } \\
\text { X receptor } \\
\text { antagonist }\end{array}$ \\
\hline Pacifenol & $\begin{array}{l}\text { Seaweeds of the marine } \\
\text { alga Laurencia claviformis }\end{array}$ & COX Inhibitors \\
\hline
\end{tabular}

Marine fungi living in challenging conditions are believed to be shown a great interest and they are paid a great amount of attention; thefore, they are highly regarded as a source of new and promising as well as effective bioactive products. Since marine organisms live in biologically competitive environments with different $\mathrm{pH}$, temperature, pressure, oxygen, light, nutrients and salinity conditions, the chemical diversity of the secondary metabolites obtained from them is quite high.

It is inevitably thought that the fungi living in the terrestrial environment have been transported to the seas by rivers, rain or some other reasons. Also, they usually live in seawater or settle in sediments with a dense population. Some have gradually adapted to the conditions of the marine environment and have been successful to survive. Cuomo et al. (1995) reported that the percentage of antibiotic production from sea fungi was higher than terrestrial fungi. This suggests that not only antibiotics but also many bioactive substances derived from marine fungi can have a much higher bioactivity than terrestrial ones (Tsuchiya et al., 2008). In this respect, many microorganisms have been isolated from the marine environment to obtain new substances. Many compounds are known to have been identified as tyrosinase inhibitors from plants, microorganisms and, synthetic compounds. In recent years, marine microorganisms that produce bioactive compounds have been noted and several new compounds have been isolated.

Sea sponges: Sea sponges are regarded as a renewable natural resource and they are considered to be highly absorbent, foam-forming, to have a soft texture and they are believed to be rather suitable for the use of the most sensitive skin.

Natural marine sponges are widely known to contain enzymes and to prevent the formation of mold and bacteria. On the other hand, natural sea sponges have been developed for bathing and cleaning in that they absorb and retain a lot of water. Even though sponges are mainly used to clean the body and face, they are also known to be used to clean the skin of babies. Furthermore, they are effectively used as a skin whitening compound (Uppala, 2015).

In a different study conducted by Lee et al. (2016), they isolated oxygenated diterpenoid Gagunin D (GD) from the sea sponge Phorbas sp. In this study, they found out that GD inhibits tyrosinase enzymatic activity as well as cytotoxicity activity against human leukemia cells. In addition, they reported that GD expresses proteins associated with melanosomal transfer. Because of these distinguishing properties, GD has been reported to be a potential candidate for cosmetic formulations.

In another study on sponges, Geoditin A was isolated from the Geodia japonica. This substance has isobarbaric triterpene structure and exhibits melanogenesis inhibition (Chang, 2012). Studies show that Geoditin A induces apoptosis through oxidative stress in leukemia HL60 cells and human colon HT29 cancer cells. The strong anti-melanogenic activity and the relatively low cytotoxicity of Geoditin A showed its therapeutic potential as a skin lightening agent (Cheung et al., 2012).

In another study conducted for marine fungi obtained from Haliclona fascigera sponge collected from the South Coast of West Sumatera, ethyl acetate extracts were taken and found to act as tyrosinase inhibitors. Four out of a total of 20 extracts, WR3, WR4, WR9, and WR13 showed the highest inhibition. These fungi are examined and identified as Penicillium sp. (WR3), Aspergillus niger (WR4), Penicillium sp.3 (WR9) and Trichophyton megninii (WR13) (Handayani et al., 2019).

Marine fungus: Marine derived fungi have been reported to produce a wide range of active compounds which have a certain amount of effects on central nervous system, respiratory system, neuromuscular system, autonomic nervous system, cardiovascular system and gastrointestinal 
system Furthermore, these compounds have been shown to be effective for antibacterial, antifungal, antidiabetic, antiinflammatory, antiprotozoal, anti-tuberculosis, antiviral, antitumor, and cytotoxic activities (Abd El Hady et al., 2014; Christophersen et al., 1998; Hasan et al., 2015; Luo et al., 2017; Moghadamtousi et al., 2015; Pontius et al., 2008; Ramos et al., 2015; Zolghadri et al., 2019).

Most fungi are found with algae. As such in a later study carried out to serve for the same purpose, Botrytis sp. was collected from the red algae Hyalosiphonia caespitosa and the extract of this algae showed tyrosinase inhibitory activity (Sumathy and Kim, 2011; Zhang et al., 2007)

In another study, two fungi (FS1 and FS3) were isolated from sponges; Amphimed onviridis and Agelas sp. Tyrosinase inhibiting activities were evaluated and it revealed that FS3 has an important activity (Abd El Hady et al., 2014).

In the study of Li et al. (2005), new myrothenones A (4) and $B(5)$, were isolated together with known 6-n-pentyl-apyrone (1), trichodenone A (2), and cyclonerodiol (3) from the marine derived fungus Myrothecium (Figure 2). It was isolated from the surface of the sea-green algae Enteromorpha compressa collected by Busan Baegunpo, Busan in 2002 (Li et al., 2005).<smiles>CCCCCc1cccc(=O)o1</smiles>

6-n-penthyl-a-pyrone

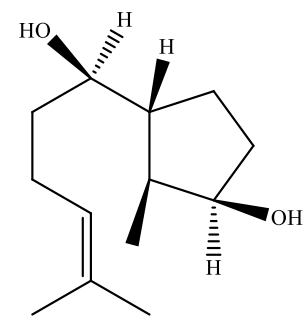

Cyclonerodiol (3)

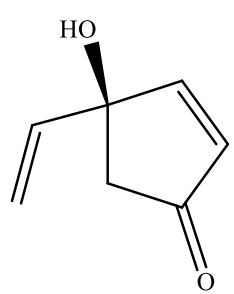

Trichodenone A (2)

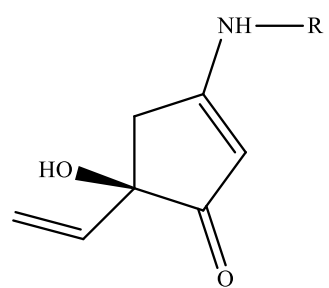

$\mathrm{R}=\mathrm{CHO}:$ myrothenone $\mathrm{A}(4)$

$\mathrm{R}=\mathrm{H}$ : myrothenone $\mathrm{B}(5)$ $\mathrm{R}=\mathrm{COC}_{6} \mathrm{H}_{4} \mathrm{Br}: \mathrm{p}-$ bromobenzoate (5a)
Figure 2. The structure of defined substances

Tsuchiya and colleagues have worked on the Trichoderma viride strain $\mathrm{H} 1-7$ isolated from the 100-meter deep-sea sedimentation of the Izu Islands and found that this strain exhibited tyrosinase inhibitory activity. Four types of fungal tyrosinase inhibitors were obtained from this sediment (Figure 2). In addition, strain $\mathrm{H} 1-7$ has been shown to produce melanogenesis inhibitors. Three of these compounds are completely different from fungal tyrosinase inhibitors (Tsuchiya et al., 2008).
In the mentioned study, they purified the tyrosinase inhibitor produced by Trichoderma viride strain $\mathrm{H} 1-7$ from a marine environment. The purified inhibitor's chemical structure was determined and it is found to be the same as homothallin II isolated from Trichoderma koningii and $T$. harzianum as an antibiotic (Figure 3). However, it may be stated that this compound has not been reported to have tyrosinase inhibitory activity in the literature (Tsuchiya et al., 2008).

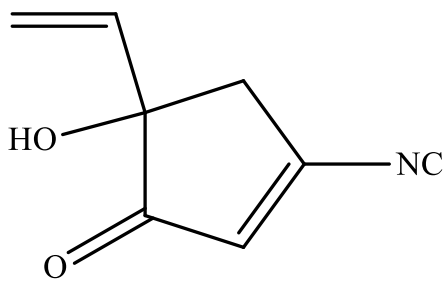

Figure 3. Chemical Structure of the Tyrosinase Inhibitor Produced by Tricoderma viride Strain $\mathrm{H} 1-7$

In another study, two new tyrosinase inhibitors were obtained from Pestalotiopsis sp.Z233 exhibiting a considerable amount of strong tyrosinase inhibitory activities. The inhibitors produced under abiotic stress with $\mathrm{CuCl}_{2}(\mathrm{Wu}$ et al., 2013).

Trianto et al. (2017) were studied on Aspergillus sydowii fungi that are considered to be a symbiotic fungus of marine sponge Axinella sp. and identified to have antibacterial effects. It is also known that $A$. sydowii has activities such as tyrosinase inhibitor, antimicrobial, anti-tuberculosis and acetylcholinesterase inhibitor.

Seaweed: Seaweed is known to be classified as brown, red, and green. They are believed to be commonly used as food in East Asian countries. Furthermore, they are claimed to have a different promising class of bioactive secondary metabolites such as; terpenoids, polyphenols, peptides, carotenoids, fatty acids, and phytohormones. In this respect, additionally, fluorotannins are known to be lipolytic agents that inhibit melanogenesis effectively (Pereira, 2015; Wijesinghe and Jeon, 2011)

Seaweed has been known to be used for skin care products for hundreds of years for circulation and balance of natural moisture levels. The main uses and benefits of seaweed extract are highly believed to be anti-acne, to have positive and promising effects on blood circulation activating the cell renewal, the metabolism, anti-aging, anti-inflammatory and skin whitening. In a study conducted in the related field, it is examined and the result is that the French Silab company has launched a new bleaching product (Whitonyl囚) from Palmaria palmata (red algae) of which the main compounds are known to be oligosaccharides and the product is proved to lighten deep wrinkles, age spots and brown spots caused by exposure to chronic sunlight giving the skin a more homogenous and opal appearance (Pereira, 2018). 
<smiles>Oc1cc(O)cc(O)c1</smiles>

phloroglucinol

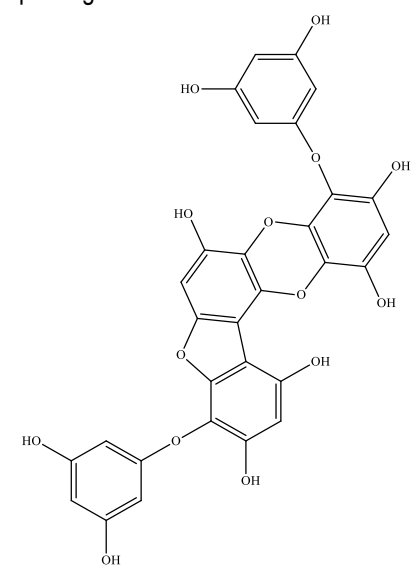

phlorofuroeckol A<smiles>Cc1cc(O)c2oc3ccc4oc5cc(O)cc(C)c5oc4c3oc2c1</smiles>

eckstolonol<smiles>Cc1cc(C)cc(Oc2cc(C)c(Oc3c(C)cc(C)c4c3Oc3c(C)cc(C)cc3O4)c(Oc3cc(C)c4oc5c(Oc6cc(C)cc(C)c6)c(C)cc(C)c5c4c3)c2)c1</smiles><smiles>Cc1cc(C)cc(Oc2cc(C)cc(O)c2Oc2cc(C)cc(O)c2)c1</smiles>

eckol

Figure 4. The Structures of the Phlorotannins from E. stolonifera

Ecklonia stolonifera is widely known to be a perennial brown seaweed that grows at a depth of 2-10 meters. Moreover, it is generally found in Korea and Japan and is often used as a foodstuff together with Laminaria japonica and Undaria pinnatifida. Phloroglucinol and its derivatives, ecklonia lactones were isolated from $E$. stolonifera. In addition, a certain and promising amount of studies have shown that algae have a skin-opening effect as well as an appetite suppression, antioxidant and antimutagenic activity.

In order to explore the sources with tyrosinase inhibitory activity in seaweeds, the inhibitory effects of 17 seaweed extracts, i.e. 2 Chlorophyta, 5 Phaeophyta and 10 Rhodophyta branches on fungal tyrosinase activity as substrate using L-tyrosine were investigated. Of these, only $E$. stolonifera exhibited an inhibitory activity with an IC50 value of 345 microgram / mL. Others showed the inhibitory activity of less than $50 \%$ at the highest concentration of 500 micrograms $/ \mathrm{ml}$. The bioassay-guided fraction of the active ethyl acetate soluble fraction from the methanolic extract of $E$. stolonifera has led to the isolation of phloroglucinol derivatives (Figure 4) (Kang et al., 2004).

Wachi et al. (1995) carried out a study on 127 marine microalgae isolates using both water (saline/buffer) and organic solvent to find out marine tyrosinase inhibitors secondary metabolites. The results suggest that marine cyanobacteria, especially members of the genus
Synechococcus, may be used for photosynthetic production of tyrosinase inhibitors for biomedical applications. Cha et al. (2011) carried out a study on 43 seaweed to investigate tyrosinase inhibitory activity. Some of them (Endarachne binghamiae, Ecklonia cava, Schizymenia dubyi and Sargassum silquastrum) showed potent tyrosinase-inhibiting activity like kojic acid (Matsukawa et al., 1997).

A surprisingly interesting fungi strain was collected from the surface of the edible red algae Gracilaria verrucosa and the brown algae Sargassum horneri, from the Yokji Island of Gyeongnam. The cyclopentenone structure, myrotenone A, was isolated from this fungi identified as Trichoderma viride. This compound showed a strong tyrosinase inhibitory activity with an ED50 value of $6.6 \mu \mathrm{M}$, which is more active than a positive standard kojic acid (ED50, 7.7M) (Wu and Naranmadura, 2014).

Symphyocladia latiuscula (Harvey) Yamada (Rhodomelaceae), and sea-red alga which contain bromophenol exhibiting a wide range of biological activities. Paudel et al. (2019) investigated the anti-tyrosinase activity of the alga and from three bromophenols isolated from the alga two of them showed an activity against L-tyrosine substrates.

In another research, six known bromophenol dimers were purified from the extract of red algae Odonthalia corymbifera. Both symmetric and asymmetric bromophenols showed tyrosinase inhibitory activities. Of these, asymmetric dimer 6 and symmetric dimer 1 and 2 exhibited a very strong tyrosinase inhibition (Figure 5) (Mr et al., 2017). 
<smiles>Oc1cc(COCc2cc(O)c(O)c(Br)c2Br)c(Br)c(Br)c1O</smiles>

1<smiles>Oc1cc(Cc2cc(O)c(O)c(Br)c2Br)c(Br)c(Br)c1O</smiles>

2<smiles>[R]OCc1cc(O)c(O)c(Br)c1Cc1cc(O)c(O)c(Br)c1Br</smiles>

$\mathrm{R}=\mathrm{H} 3$<smiles>COCc1cc(O)c(O)c(Cc2cc(O)c(O)c(Br)c2Br)c1Br</smiles>

5<smiles>COCc1c(Br)c(Br)c(O)c(O)c1Cc1cc(O)c(O)c(Br)c1Br</smiles>

6

Figure 5. The structure of defined

Sargassum plagyophyllum obtained from Pasauran coastal waters is highly believed to contain quite influential as well as effective bioactive compounds such as alkaloids, steroids, flavonoids, saponins and tannins, whereas Eucheuma cottonii that obtained from the results of community cultivation in Lontar village, Serang, Banten (Indonesia's Pasauran coast) contains alkaloids and terpenoids. Active compounds like flavonoids are known to have tyrosinase inhibitory activities. In a study, S. plagyophyllum and E. cottonii methanol extract have shown to be more effective in the diphenolase reaction than kojic acid by inhibiting the oxidation of L-DOPA to DOPAquinone. S. plagyophyllum and $E$. cottonii extracts could be used in cosmetics as skin lightening whitening (Dolorosa et al., 2019).

Phloroglucinol derivatives, a secondary metabolite of brown algae, showed tyrosinase-inhibiting activity due to having copper chelating in the tyrosinase enzyme (Kang et al., 2004). In addition, $\beta$-carotene in seaweed species is known to be an active compound that directly inhibits tyrosinase. Fucoxanthin, a carotenoid found in seaweed Laminaria japonica, inhibited tyrosinase activity, melanogenesis and skin pigmentation due to UV-B (Sumathy and Kim, 2011).

A few studies are known to have been conducted on the skin whitening effects of marine bacteria; however, in opposition to common belief, it has been discovered that Pseudomonas produces methylene chloride that shows tyrosinase inhibitory activity (Kang et al., 2011). Moreover, some tyrosinase inhibitors ( $\mathrm{N}$-acyl dehydrotyrosine derivatives) have been reported from a gram-negative marine bacterium Thalassotalea sp. PP2-459 (Deering et al., 2016; Guillerme et al., 2017; Zolghadri et al., 2019).

During the investigation of new hypopigmenting agents from marine microbial natural products, Bacillus sp. (SCO147) was found in Gwangyang Bay in South Korea and showed hypopigmenting activity. In this study, they isolated (-) - 4-hydroxysattabacin (1, 4OH-ST) and (-) - sattabacin (2) (Figure 6). 4OH-ST and sattabacin were first obtained from a Bacillus sp. It has been found to show antiviral activities against Herpes simplex virus types 1 and 2 (Mancha et al., 2013; Lampis et al., 1995). The anti-melanogenic activity of these natural products, in particular (-) - 4OH-ST and (-) sattabacins, has not been reported yet. The efficacy of (-)$4 \mathrm{OH}-\mathrm{ST}$ (1) as an anti-melanogenic agent was discovered in Kim, Leutou, Jeong, Kim, \& Seong's study (Kim et al., 2017).<smiles>CC(C)CC(=O)[C@H](O)Cc1ccc(O)cc1</smiles>

(-) - 4-hydroxysattabacin 1<smiles>CC(C)CC(=O)[C@H](O)Cc1ccccc1</smiles>

(-) - sattabacin

2
Figure 6. The molecules from Bacillus sp.

\section{CONCLUSION}

The marine environment is highly regarded as a rich source of both biological and chemical diversity. In this regard, marine organisms are believed to produce unique and promising compounds. Therefore, as a consequence of such kind of a rich source as mentioned above, in recent years, marine-derived natural products have gained a great importance as well as a momentum for the cosmetics industry, which seems to require continuous innovations in the field. Although marine resources have not yet been fully 
explored, it is highly claimed that it has an important market in the cosmetic sector all over the world. Therefore, gaining access to marine chemical diversity including deep-sea sources is highly needed to address the huge need for new cosmetically active molecules.

As it is widely known, the cosmetics industry is considered to be a growing as well as an effectively promising market in the world. The awareness of the use of natural products instead of synthetic products seems to have increased significantly; hence, the less-discovered marine world is of interest to the cosmetics industry.

Skin whitening active ingredients, formulations, products and ongoing research, and development are known to be increasing day by day. An investigation of skin whitening mechanisms and innovative molecules involved in melanin synthesis and research on natural compounds may play an important role and may have a significant impant on the related industry for more developments as well as for further studies. In addition, the use of marine-derived active substances and extracts in the formulations of skin bleaching

\section{REFERENCES}

Abd El Hady, F., Abelaziz, M., Abdou, A.M., Shaker, K., Ibrahim, L.S. \& ElShahid, Z.A. (2014). In-vitro anti-diabetic and cytotoxic effect of the coral derived fungus (Emericella unguis 8429) on human colon, liver, breast and cervical carcinoma cell lines. International Journal of Pharmaceutical Sciences Review and Research, 27, 296-301.

Abd El Hady, F., Abelaziz, M., Shaker, K. \& El-Shahid, Z.A. (2014). Tyrosinase, acetylcholinesterase inhibitory potential, antioxidant and antimicrobial activities of Sponge derived fungi with correlation to their GC/MS analysis. International Journal of Pharmaceutical Sciences Review and Research, 26, 338-345.

Alğın Yapar, E. (2016). Cilt Beyazlatıcılara Genel Bakış. Marmara Pharmaceutical Journal, 21(24530), 48-53. DOI:10.12991/marupj.259880

Almeida, C., Part, N., Bouhired, S., Kehraus, S. \& Konig, G. M. (2011). Stachylines A-D from the sponge-derived fungus Stachylidium sp. Journal of Natural Products, 74(1), 21-25. DOI:10.1021/np1005345

Blunt, J.W., Copp, B.R., Keyzers, R.A., Munro, M.H., \& Prinsep, M.R. (2015). Marine natural products. Natural Product Reports, 31(2), 160-258. DOI:10.1039/c3np70117d

Boonme, P., Junyaprasert, V., Suksawad, N. \& Songkro, S. (2009). Microemulsions and Nanoemulsions: Novel Vehicles for Whitening Cosmeceuticals. Journal of biomedical nanotechnology, 5, 373-383. DOI:10.1166/jbn.2009.1046

Brunt, E.G. \& Burgess, J.G. (2018). The promise of marine molecules as cosmetic active ingredients. International Journal of Cosmetic Science, 40(1), 1-15. DOI:10.1111/ics.12435

Cha, S.-H., Ko, S.-C., Kim, D. \& Jeon, Y.-J. (2011). Screening of marine algae for potential tyrosinase inhibitor: Those inhibitors reduced tyrosinase activity and melanin synthesis in zebrafish. The Journal of dermatology, 38, 354-363. DOl:10.1111/j.1346-8138.2010.00983.x

Chang, T.-S. (2012). Natural Melanogenesis Inhibitors Acting Through the Down-Regulation of Tyrosinase Activity. Materials, 5(9), 1661-1685. DOI:10.3390/ma5091661

Cheung, F. W., Guo, J., Ling, Y. H., Che, C. T. \& Liu, W. K. (2012). Antimelanogenic property of geoditin A in murine B16 melanoma cells. Marine Drugs, 10(2), 465-476. DOl:10.3390/md10020465

Christophersen, C., Crescente, O., Frisvad, J. C., Gram, L., Nielsen, J., Nielsen, P. H., \& Rahbaek, L. (1998). Antibacterial activity of marinederived fungi. Mycopathologia, 143(3), 135-138. DOI:10.1023/a:1006961500325

Cooksey, C. J., Garratt, P., Land, E. J., Ramsden, C. A., Riley, P., \& Smit, N. (1997). Evidence of the Indirect Formation of the Catecholic agents will become even more important if taken into consideration with a significant amount of care to support new studies.

Since it is scientifically known that tyrosinase plays a negative role in enzymatic depigmentation disorders for humans, these inhibitors have been a major concern and focus for the researcher throughout this study. In this context, as is known, natural resources and their active compounds are believed to have promising and great potential as tyrosinase inhibitors, primarily for the cosmetics and also food industries.

These compounds were previously isolated from plants. However, as a result of recent studies, algae, sponges, fungi and bacteria have been found to be a rich source of tyrosinase inhibitors. In this article, it can be understood that numerous inhibitors derived from marine sources have been investigated in detail and summarized accordingly. The main purpose of this review is to emphasize the importance of marine tyrosinase inhibitors for the cosmetics industry, a large market.

Intermediate Substrate Responsible for the Autoactivation Kinetics of Tyrosinase. The Journal of biological chemistry, 272, 26226-26235. DOI:10.1074/jbc.272.42.26226

Corinaldesi, C., Barone, G., Marcellini, F., Dell'Anno, A., \& Danovaro, R. (2017). Marine Microbial-Derived Molecules and Their Potential Use in Cosmeceutical and Cosmetic Products. Marine Drugs, 15(4). DOI:10.3390/md15040118

Cuomo, V. P., I. ; Perretti, A. ; Guerriero, A. ; D’Ambrosio, M.; Pietra, F. (1995). Journal of Marine Biotechnology, 2, 199-204.

Çomoglu, T. (2012). Kozmetikler. Marmara Pharmaceutcal Journal, 1(16), 1 8. DOI:10.12991/201216414

D'Orazio, N., Gammone, M. A., Gemello, E., De Girolamo, M., Cusenza, S., \& Riccioni, G. (2012). Marine bioactives: pharmacological properties and potential applications against inflammatory diseases. Marine Drugs, 10(4), 812-833. DOI:10.3390/md10040812

Deering, R. W., Chen, J., Sun, J., Ma, H., Dubert, J., Barja, J. L.,Seeram, N.P.,Wang, H.,Rowley,D. C. (2016). N-Acyl Dehydrotyrosines, Tyrosinase Inhibitors from the Marine Bacterium Thalassotalea sp. PP2459. Journal of Natural Products, 79(2), 447-450.

DOI:10.1021/acs.jnatprod.5b00972

Dolorosa, M., Nurjanah, N., Purwaningsih, S., Anwar, E., \& Hidayat, T. (2019). Tyrosinase inhibitory activity of Sargassum plagyophyllum and Eucheuma cottonii methanol extracts. IOP Conference Series: Earth and Environmental Science, 278, 012020. DOI:10.1088/1755-1315/278/1/012020

Fiorucci, S., Distrutti, E., Bifulco, G., D'Auria, M. V., \& Zampella, A. (2012). Marine sponge steroids as nuclear receptor ligands. Trends in Pharmacological Sciences, 33(11), 591-601. DOI:10.1016/j.tips.2012.08.004

Guillerme, J.-B., Couteau, C., \& Coiffard, L. (2017). Applications for Marine Resources in Cosmetics. Cosmetics, 4(3), 35. DOI:10.3390/cosmetics4030035

Handayani, D., Sandrawati, N., Akbar, S., Syafni, N., \& Putra, D. (2019). Tyrosinase Inhibitory Activity of Ethyl Acetate Extracts from Marine Sponge-Derived Fungi Haliclona fascigera. Bioscience Research, 16, 2369-2373.

Hasan, S., Ansari, M. I., Ahmad, A., \& Mishra, M. (2015). Major bioactive metabolites from marine fungi: A Review. Bioinformation, 11(4), 176181. DOI: $10.6026 / 97320630011176$ 
Kang, H. S., Kim, H. R., Byun, D. S., Son, B. W., Nam, T. J., \& Choi, J. S (2004). Tyrosinase inhibitors isolated from the edible brown alga Ecklonia stolonifera. Archives of Pharmacal Research, 27(12), 12261232. DOI:10.1007/bf02975886

Kang, H. Y., Yoon, T., \& Lee, G. (2011). Whitening Effects of Marine Pseudomonas Extract. Annals of Dermatology, 23(2), 144-149. DOI:10.5021/ad.2011.23.2.144

Kim, K., Leutou, A. S., Jeong, H., Kim, D., Seong, C. N., Nam, S. J., \& Lim, K. M. (2017). Anti-Pigmentary Effect of (-)-4-Hydroxysattabacin from the Marine-Derived Bacterium Bacillus sp. Marine Drugs, 15(5). DOI:10.3390/md15050138

Kjer, J., Debbab, A., Aly, A. H., \& Proksch, P. (2010). Methods for isolation of marine-derived endophytic fungi and their bioactive secondary products. Nature Protocols, 5(3), 479-490. DOI:10.1038/nprot.2009.233

Kubo, I., Kinst-Hori, I., Chaudhuri, S. K., Kubo, Y., Sanchez, Y., \& Ogura, T. (2000). Flavonols from Heterotheca inuloides: tyrosinase inhibitory activity and structural criteria. Bioorganic \& Medicinal Chemistry, 8(7) 1749-1755. DOI:10.1016/s0968-0896(00)00102-4

Lampis, G., Deidda, D., Maullu, C., Madeddu, M. A., Pompei, R., Delle Monachie, F., \& Satta, G. (1995). Sattabacins and sattazolins: new biologically active compounds with antiviral properties extracted from a Bacillus sp. The Journal of Antibiotics, 48(9), 967-972. DOI:10.7164/antibiotics.48.967

Lee, H. Y., Jang, E. J., Bae, S. Y., Jeon, J. E., Park, H. J., Shin, J., \& Lee, S K. (2016). Anti-Melanogenic Activity of Gagunin D, a Highly Oxygenated Diterpenoid from the Marine Sponge Phorbas sp., via Modulating Tyrosinase Expression and Degradation. Marine Drugs, 14(11). DOI:10.3390/md14110212

Lee, Y.-M., Dang, H. T., Li, J., Zhang, P., Hong, J.-K., Lee, C.-O., \& Jung, J.H. (2011). A Cytotoxic Fellutamide Analogue from the Sponge-Derived Fungus Aspergillus versicolor. Bulletin of the Korean Chemical Society, 32(10), 3817-3820. DOI:10.5012/bkcs.2011.32.10.3817

Li, X., Kim, M. K., Lee, U., Kim, S. K., Kang, J. S., Choi, H. D., \& Son, B. W. (2005). Myrothenones A and B, cyclopentenone derivatives with tyrosinase inhibitory activity from the marine-derived fungus Myrothecium sp. Chemical and Pharmaceutical Bulletin (Tokyo), 53(4), 453-455. DOI:10.1248/cpb.53.453

Liu, Q., Xu, H., Zhang, T., Fan, X., \& Han, L. (2006). A new compound as PTP1B inhibitor from the red alga Polysiphonia urceolata. Chemistry Bulletin / Huaxue Tongbao, 69, 708-710.

Lo, Y. H., Lin, R. D., Lin, Y. P., Liu, Y. L., \& Lee, M. H. (2009). Active constituents from Sophora japonica exhibiting cellular tyrosinase inhibition in human epidermal melanocytes. Journal of Ethnopharmacology, 124(3), 625-629. DOI:10.1016/j.jep.2009.04.053

Luo, X., Zhou, X., Lin, X., Qin, X., Zhang, T., Wang, J.,Tu, Z.,Yang, B.,Liao, S.,Tian, Y.,Pang, X., Kaliyaperumal, K., Li, J. L., Tao, H., Liu, Y. (2017). Antituberculosis compounds from a deep-sea-derived fungus Aspergillus sp. SCSIO Ind09F01. Natural Product Research, 31(16), 1958-1962. DOI:10.1080/14786419.2016.1266353

Mancha, S. R., Regnery, C. M., Dahlke, J. R., Miller, K. A., \& Blake, D. J. (2013). Antiviral activity of (+)-sattabacin against Varicella zoster. Bioorganic \& Medicinal Chemistry Letters, 23(2), 562-564. DOI:10.1016/j.bmcl.2012.11.017

Martins, A., Vieira, H., Gaspar, H., \& Santos, S. (2014). Marketed marine natural products in the pharmaceutical and cosmeceutical industries: tips for success. Marine Drugs, 12(2), 1066-1101. DOI:10.3390/md12021066

Matsukawa, R., Dubinsky, Z., Masaki, K., Takeuchi, T., \& Karube, I. (1997). Enzymatic screening of microalgae as a potential source of natural antioxidants. Applied Biochemistry and Biotechnology, 66(3), 239-247. DOI:10.1007/bf02785590

Moghadamtousi, S. Z., Nikzad, S., Kadir, H. A., Abubakar, S., \& Zandi, K. (2015). Potential Antiviral Agents from Marine Fungi: An Overview. Marine Drugs, 13(7), 4520-4538. DOI:10.3390/md13074520

Mora, C., Tittensor, D. P., Adl, S., Simpson, A. G., \& Worm, B. (2011). How many species are there on Earth and in the ocean? PLOS Journals, 9(8), e1001127. DOI:10.1371/journal.pbio.1001127

Mostafa, E. R., Wael, E. H., Nathalie, M. L., Carol, C., Marcel, J., \& Rainer, E. (2010). Dibenzofurans from the marine sponge-derived ascomycete
Super1F1-09. Botanica Marina, 53(6), 499-506.

DOI:10.1515/bot.2010.064

Mr, I., Mikami, D., Kurihara, H. (2017). Tyrosinase Inhibitory and Antioxidant Activity by Bromophenols from the Alga Odonthalia corymbifera. Natural Products: An Indian Journal, 13(2), 110

Muda, H., Aziz, A., Taher, Z., \& Aziz, R. (2017). Cosmeceuticals and Natural Cosmetics. In R. Hasham (Ed.), Recent Trends in Research into Malaysian Medicinal Plants (First ed., pp. 126-175): penerbit UTM Press.

Nastrucci, C., Cesario, A., \& Russo, P. (2012). Anticancer Drug Discovery from the Marine Environment. Recent patents on anti-cancer drug discovery, 7, 218-232. DOI:10.2174/157489212799972963

No, J. K., Soung, D. Y., Kim, Y. J., Shim, K. H., Jun, Y. S., Rhee, S. H.,Yokozawa, T., Chung, H. Y. (1999). Inhibition of tyrosinase by green tea components. Life Sciences, 65(21), PI241-246. DOI:10.1016/s0024-3205(99)00492-0

Parvez, S., Kang, M., Chung, H. S., \& Bae, H. (2007). Naturally occurring tyrosinase inhibitors: mechanism and applications in skin health, cosmetics and agriculture industries. Phytotherapy Research, 21(9), 805-816. DOI:10.1002/ptr.2184

Paudel, P., Wagle, A., Seong, S. H., Park, H. J., Jung, H. A., \& Choi, J. S. (2019). A New Tyrosinase Inhibitor from the Red Alga Symphyocladia latiuscula (Harvey) Yamada (Rhodomelaceae). Marine Drugs, 17(5). DOI:10.3390/md17050295

Pereira, L. (2015). Seaweed Flora of the European North Atlantic and Mediterranean. In (pp. 65-178).

Pereira, L. (2018). Seaweeds as Source of Bioactive Substances and Skin Care Therapy-Cosmeceuticals, Algotheraphy, and Thalassotherapy. Cosmetics, 5(4), 68. DOI:10.3390/cosmetics5040068

Pillaiyar, T., Manickam, M., \& Namasivayam, V. (2017). Skin whitening agents: medicinal chemistry perspective of tyrosinase inhibitors. Journal of Enzyme Inhibition and Medicinal Chemistry, 32(1), 403-425. DOI:10.1080/14756366.2016.1256882

Pontius, A., Krick, A., Kehraus, S., Brun, R., \& Konig, G. M. (2008). Antiprotozoal activities of heterocyclic-substituted xanthones from the marine-derived fungus Chaetomium sp. Journal of Natural Products, 71(9), 1579-1584. DOI:10.1021/np800294q

Ramos, A. A., Prata-Sena, M., Castro-Carvalho, B., Dethoup, T., Buttachon, S., Kijjoa, A., \& Rocha, E. (2015). Potential of four marine-derived fungi extracts as anti-proliferative and cell death-inducing agents in seven human cancer cell lines. Asian Pacific Journal of Tropical Medicine, 8(10), 798-806. DOI:10.1016/j.apjtm.2015.09.005

Rodriguez-López J. , N., Tudela, J., Varón, R., \& Garcia-Cánovas, F. (1991) Kinetic study on the effect of $\mathrm{pH}$ on the melanin biosynthesis pathway. Biochimica et biophysica acta, 1076(3), 379-386. Retrieved from http://www.biomedsearch.com/nih/Kinetic-study-effect-pHmelanin/1900435.html

Shen, C., Chen, P., Wu, J., Lee, T., Hsu, S., Chang, C., Chiu-Chung, Y. Shieh, C. (2011). Purification of algal anti-tyrosinase zeaxanthin from Nannochloropsis oculata using supercritical anti-solvent precipitation. The Journal of Supercritical Fluids, 55(3), 955-962. DOI:10.1016/j.supflu.2010.10.003

Shimizu, K., Kondo, R., \& Sakai, K. (2000). Inhibition of tyrosinase by flavonoids, stilbenes and related 4-substituted resorcinols: structureactivity investigations. Planta medica, 66(1), 11-15. DOI:10.1055/s-2000-11113

Sugumaran, M. (1991). Molecular mechanisms for mammalian melanogenesis: Comparison with insect cuticular sclerotization ${ }^{1}$. FEBS Letters, 295(1), 233-239. DOI:10.1016/0014-5793(91)81431-7

Sumathy, B., \& Kim, E.-K. (2011). Effect of Marine Cosmeceuticals on the Pigmentation of Skin. In S-K. Kim (Ed.), Marine Cosmeceuticals Trends and Prospects (pp. 63-66) Boca Raton: Crs Press.

Thirunavukkarasu, N., Suryanarayanan, T., Girivasan, K.P., Ambayeram, V., Greetha, V., Ravishankar, J. \& Doble, M. (2012). Fungal symbionts of marine sponges from Rameswaram, southern India: Species composition and bioactive metabolites. Fungal diversity, 2. DOI:10.1007/s13225-011-0137-6

Trianto, A., Widyaningsih, S., Radjasa, O. K., \& Pribadi, R. (2017). Symbiotic Fungus of Marine Sponge Axinella sp. Producing Antibacterial Agent. 
IOP Conference Series: Earth and Environmental Science, 55, 012005 DOI:10.1088/1755-1315/55/1/012005

Tsuchiya, T., Yamada, K., Minoura, K., Miyamoto, K., Usami, Y., Kobayashi, T., Hamada-Sato, N., Imada, C., Tsujibo, H. (2008). Purification and determination of the chemical structure of the tyrosinase inhibitor produced by Trichoderma viride strain $\mathrm{H} 1-7$ from a marine environment. Biological and Pharmaceutical Bulletin, 31(8), 1618-1620.

DOI:10.1248/bpb.31.1618

Uppala, L. (2015). A Review on Active Ingredients from Marine Sources used in Cosmetics. SOJ Pharmacy and Pharmaceutical Sciences, 2(3), 1-3.

Vamos-Vigyazo, L. (1981). Polyphenol oxidase and peroxidase in fruits and vegetables. Critical Reviews in Food Science and Nutrition, 15(1), 49127. DOl:10.1080/10408398109527312

Wachi, Y. B., J. G.; Takahashi, J.; Nakamura, N.; Matsunaga, T. (1995). Tyrosinase inhibition by the water-soluble fraction of marine microalgae. J. Mar. Biotechnol., 2, 210-213. Retrieved from https://ci.nii.ac.jp/naid/10014710487/en/

Whitaker, J. R. (1994). Prenciples of enzymology for the food sciences (Second ed.). Marcel Dekker,Inc.
Wijesinghe, W. A. J. P., \& Jeon, Y.-J. (2011). Biological activities and potential cosmeceutical applications of bioactive components from brown seaweeds: A review. Phytochemistry Reviews, 10, 431-443. DOI:10.1007/s11101-011-9214-4

Wu, B., \& Naranmadura, H. (2014). Tyrosinase Inhibitors from Terrestrial and Marine Resources. Current topics in medicinal chemistry, 14. DOI:10.2174/1568026614666140523115357

Wu, B., Wu, X., Sun, M., \& Li, M. (2013). Two novel tyrosinase inhibitory sesquiterpenes induced by $\mathrm{CuCl}_{2}$ from a marine-derived fungus Pestalotiopsis sp. Z233. Marine Drugs, 11(8), 2713-2721. DOI:10.3390/md11082713

Zhang, D., Li, X., Kang, J., Choi, H., \& Son, B. (2007). A New a-Pyrone Derivative, 6-[(E)-Hept-1-enyl]-a-pyrone, with Tyrosinase Inhibitor Activity from a Marine Isolate of the Fungus Botrytis. Cheminform, 38. DOI:10.1002/chin.200740195

Zolghadri, S., Bahrami, A., Hassan Khan, M. T., Munoz-Munoz, J., GarciaMolina, F., Garcia-Canovas, F., \& Saboury, A. A. (2019). A comprehensive review on tyrosinase inhibitors. Journal of Enzyme Inhibition and Medicinal Chemistry, 34(1), 279-309. DOI:10.1080/14756366.2018.1545767 